\title{
End-products, Fermentation Balances and Molar Growth Yields of Homofermentative Lactobacilli
}

\author{
By H. DIRAR* AND E. B. COLLINS \\ Department of Food Science and Technology, University of California, \\ Davis, California, 95616, U.S.A.
}

(Received 22 May 1972)

\begin{abstract}
SUMMARY
$Y$ (glucose) values for Lactobacillus plantarum, L. delbrueckii, L. casei, L. lactis and $L$. bulgaricus, grown as batch cultures in defined medium, and L. casei, grown in complex medium, were 20.0 to $33.3 . Y$ (galactose) values for L.plantarum were 25.7 to 32.5 . Each species produced acetate in addition to lactate, and $Y$ (ATP) values, corrected for the energy produced simultaneously with the formation of acetate, were $10 \cdot 0$ to $10 \cdot 9$, close to 10.5 , proposed as a standard value by Bauchop \& Elsden (I960). Neither formate nor ethanol was produced in more than trace quantities. $Y$ (glucose) values determined for L. lactis and L. bulgaricus at $40^{\circ} \mathrm{C}$ were less than $50 \%$ of those determined at $37^{\circ} \mathrm{C}$. Production of lactate and acetate accounted for all of the glucose utilized at both temperatures, indicating that the production of ATP by L. lactis or L. bulgaricus at $40^{\circ} \mathrm{C}$ was not coupled closely to the utilization of ATP in the synthesis of bacterial mass.
\end{abstract}

\section{INTRODUCTION}

Homofermentative lactobacilli are classic examples of organisms that employ glycolysis for energy production and ferment practically all carbohydrate to lactic acid (Elsden \& Peel, 1958; Oxenburgh \& Snowswell, 1965), though they do produce small amounts of acetic acid and $\mathrm{CO}_{2}$ (Christensen, Albany \& Pederson, 1958). Oxenburgh \& Snowswell (1965) grew Lactobacillus plantarum ATCC 8014 aerobically on limiting amounts of glucose in a defined medium and determined the molar growth yield $(Y)$ (g dry wt bacteria produced $/ \mathrm{mol}$ glucose) as $18 \cdot 8$. Assuming $Y$ (ATP) equals approximately 10.5 (Bauchop \& Elsden, 1960), this indicated that the organism had gained only 2 mol ATP $/ \mathrm{mol}$ hexose fermented and that glycolysis was the only energy-yielding pathway used. More recently, Brown (I968) reported $Y$ (glucose) for the same organism to be 22.5 when grown in complex medium under anaerobic conditions. Brown \& VanDemark (I968) found $Y$ (glucose) and $Y$ (mannitol) for L. casei grown in complex medium under aerobic conditions to be $21 \cdot 7$ and $24 \cdot 4$, respectively.

These molar growth yield determinations were not accompanied by fermentation balances and apparently did not take into account possible losses resulting from autolysis subsequent to maximal growth (Moustafa \& Collins, I968a). We have determined molar growth yields and fermentation balances for homofermentative lactobacilli, giving particular attention to the precautions summarized by Stouthamer (I969) as being necessary for accuracy.

\section{METHODS}

Organisms. The species of Lactobacillus used were L. plantarum ATCC 8014, L. casei, L. bulgaricus, $L$. lactis ATCC I235, and $L$. delbrueckii CUC-I. They were routinely subcultured

\footnotetext{
* Present address: Faculty of Agriculture, University of Khartoum, Khartoum, Sudan.
} 
every 2 weeks as stab cultures in the basal medium with $\mathrm{I} \cdot 5 \%$ Bacto-agar (Difco) and $2 \%$ glucose added. Inocula for experiments to determine yields were grown in test tubes containing $10 \mathrm{ml}$ medium. Growth temperatures were $30^{\circ} \mathrm{C}$ for L. plantarum and L. casei; $37^{\circ} \mathrm{C}$ for L. delbrueckii and $37^{\circ} \mathrm{C}$ or $40^{\circ} \mathrm{C}$ for L. lactis and L. bulgaricus. Bacteria in the exponential growth phase were harvested by filtering through a Sartorius filter (pore size, $0.45 \mu \mathrm{m}$ ), washed twice with basal medium (without energy source), and suspended in $5 \mathrm{ml}$ basal medium.

Media. The defined medium of Henderson \& Snell (I948), as modified by Oxenburgh \& Snowswell (1965), was used except that salts B (MacLeod \& Snell, 1947) replaced salts C unless indicated otherwise (salts $\mathrm{C}$ contain a higher concentration of minerals than salts $\mathrm{B}$ ). This is referred to as basal medium. The complex medium was that of de Vries, Kapteijn, van der Beek \& Stouthamer (1970) though with Difco instead of Oxoid ingredients. Media were adjusted to $\mathrm{pH} 6 \cdot 8 \pm 0 \cdot \mathrm{I}$. Glucose solutions were sterilized by filtering through a microporous porcelain filter (no. VFA-54-03; Selas Flotronics, Springhouse, Pennsylvania, U.S.A.) and added aseptically.

Cultivation methods. Cultures were grown in $200 \mathrm{ml}$ medium contained in large test tubes $(40 \times 290 \mathrm{~mm})$ fitted with sampling assemblies which were partly immersed in a thermostatically controlled water bath. Cultures were agitated using Teflon-coated magnetic stirrers. Samples were obtained with a sterile syringe through a rubber septum in the sampling assembly. The gas drawn out of the test tube to force culture into the sampling assembly was replaced with sterile air. For anaerobic conditions, cultures were sparged continuously with nitrogen ( $99.99 \%$ purity) which had passed first through a sequence of alkaline pyrogallol, distilled water and two tubes of glass wool as described by Moustafa \& Collins (I968 a).

Growth and yield measurements. Growth was followed by measuring extinction, E, at $600 \mathrm{~nm}$ with a Beckman spectrophotometer, model DB, with I cm cuvettes. Bacterial mass was determined from a standard curve relating $E$ to dry weight. $E$ corresponding to I $\mathrm{mg}$ dry wt/ml for Lactobacillus plantarum, L. casei, L. delbrueckii and L. lactis $\left(37\right.$ or $\left.40^{\circ} \mathrm{C}\right)$ was $4.00,3.54,3.79$ and 3.89 , respectively, and for L. bulgaricus $3.13\left(37^{\circ} \mathrm{C}\right)$ and $6.67\left(40^{\circ} \mathrm{C}\right)$. This relationship was linear up to at least an $E$ of $0 \cdot 7$.

Analytical methods. Glucose was determined colorimetrically with a Glucostat (Worthington Biochemical Corporation, Freehold, New Jersey, U.S.A.) by the procedure of Chayken (I966). Lactic acid was determined by the colorimetric method of Barker \& Summerson (I94I), ethanol by alcohol Stat Pack (Worthington Biochemical Corporation), total volatile acids by the procedure of Neish (1950), and formate by the method of Wood \& Gest (1957). Acetate was determined by subtracting formate from total volatile acids.

Radioisotope analysis. Lactobacillus plantarum was grown in basal medium containing 3 or $6 \mu \mathrm{mol}$ glucose $/ \mathrm{ml}$ plus, per $\mathrm{ml}, 0.0 \mathrm{I} 2$ or $0.024 \mu \mathrm{Ci}$ of $\left[\mathrm{U}-{ }^{14} \mathrm{C}\right]$ glucose (sp. act. $\left.9.6 \mathrm{mCi}\right]$ mmol; Schwarz-Mann Laboratories, Orangeburg, New York, U.S.A.). At maximum $E$, samples of the bacteria were collected on millipore filters (Millipore Corporation, Bedford, Massachusetts, U.S.A.), washed with 40 to $50 \mathrm{vol}$. of deionized distilled water, and some were treated with chloroform, ether, methanol, and ethanol (separately and in combinations) to extract lipids. The filters were dried, and radioactivity was determined (efficiency, 75 to $80 \%$ ) with a Nuclear-Chicago liquid scintillation spectrometer (Model Unilux II; NuclearChicago Corporation, Des Plaines, Illinois, U.S.A.). Samples in each case were in duplicate, and radioactivity determinations were corrected for background. 


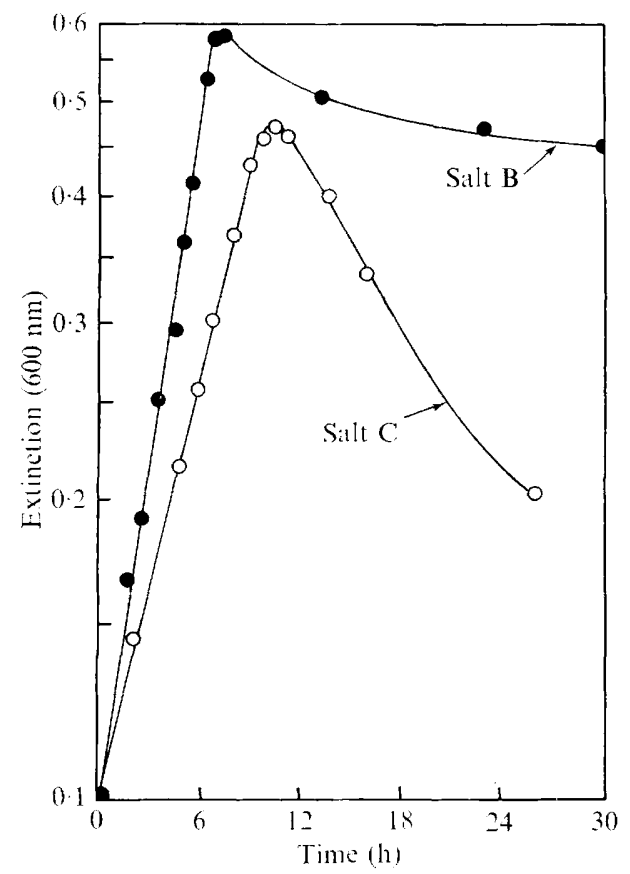

Fig. I. Influence of salts B (MacLeod \& Snell, 1947) or salts C (Henderson \& Snell, 1948) on growth and subsequent autolysis of Lactobacillus plantarum ATCC 80I4. The defined medium of Henderson \& Snell (I948) as modified by Oxenburgh \& Snowswell (I965) contained $5 \mu \mathrm{mol}$ glucose $/ \mathrm{ml}$ and salts $B$ or salts $C$.

\section{RESULTS}

\section{Growth and autolysis in defined medium}

The basal medium supplemented with glucose or galactose supported good growth of each bacterium when grown in deep culture or shaken gently in an atmosphere of air. Doubling times were 2.5 to $4.0 \mathrm{~h}$. The medium did not support growth of Lactobacillus plantarum (the only species tested) if the conditions were strictly anaerobic. (A similar finding was reported for L. casei by Erkama, Kauppien \& Heino, 1968, and for L. pasteurianus by Weinfurtner, Uhl \& Ott, I960.) However, the complex medium supported good growth of $L$. plantarum under strictly anaerobic conditions.

After achieving maximum growth in basal medium supplemented with growth-limiting amounts of glucose, each species exhibited the lytic phenomenon reported for species of Streptococcus by Moustafa \& Collins (1968a, b). Studies with Lactobacillus plantarum revealed that autolysis did not occur if galactose replaced glucose in the medium. Autolysis increased considerably if salts C (Henderson \& Snell, 1948) were supplied in place of salts B (Fig. I).

\section{Molar growth yields}

Yields, end-products and the calculated $Y(\mathrm{ATP})$ values for the five species of Lactobacillus are given in Table I. Y(glucose) values varied from 20.0 to 33.3 , but $Y$ (ATP) for each of the organisms, when corrected for acetate production, was very close to the value of 10.5 recorded by Bauchop \& Elsden (1960). The constancy of Y(ATP) was not altered by substituting complex medium for the basal medium, anaerobic conditions for the usual 
Table I. Molar growth yields and end-products produced from glucose or galactose by homofermentative lactobacilli

\begin{tabular}{|c|c|c|c|c|c|c|c|c|}
\hline \multirow[b]{2}{*}{ Species } & \multirow[b]{2}{*}{$\begin{array}{l}\text { Growth } \\
\text { tempera- } \\
\text { ture }\left({ }^{\circ} \mathrm{C}\right)\end{array}$} & \multirow{2}{*}{$\begin{array}{l}\text { Substrate } \\
\text { concen- } \\
\text { tration } \\
(\mu \mathrm{mol} / \mathrm{ml})\end{array}$} & \multicolumn{3}{|c|}{$\begin{array}{l}\text { End-products*/mol } \\
\text { substrate }\end{array}$} & \multirow{2}{*}{$\begin{array}{l}Y(\text { sub- } \\
\text { strate }) \\
\text { (g dry } \\
\text { wt } / \text { mol })\end{array}$} & \multirow[b]{2}{*}{$\begin{array}{l}\text { ATP/mol } \\
\text { substrate } \dagger \\
\quad(\mathrm{mol})\end{array}$} & \multirow[b]{2}{*}{$\begin{array}{l}\text { Y(ATP } \\
\text { (g dry } \\
\text { wt/mol) }\end{array}$} \\
\hline & & & $\begin{array}{c}\text { Lactate } \\
(\mathrm{mol})\end{array}$ & $\begin{array}{c}\text { Acetate } \\
\text { (mol) }\end{array}$ & $\begin{array}{c}\text { Total* } \\
\text { (mol) }\end{array}$ & & & \\
\hline \multicolumn{9}{|c|}{ Glucose } \\
\hline $\begin{array}{l}\text { Lactobacillus } \\
\text { plantarum }\end{array}$ & 30 & 3 to 15 & $1 \cdot 67$ & 0.34 & $2 \cdot 01$ & $25 \cdot 7$ & $2 \cdot 35$ & $10 \cdot 9$ \\
\hline L. delbrueckii & 37 & 3 to 18 & $I \cdot 66$ & 0.35 & $2 \cdot 0 \mathrm{I}$ & $23 \cdot 6$ & $2 \cdot 36$ & $10 \cdot 0$ \\
\hline L. lactis & 37 & 2 to 5 & $\mathrm{I} \cdot 57$ & 0.47 & $2 \cdot 04$ & $25 \cdot 0$ & $2 \cdot 51$ & $10 \cdot 0$ \\
\hline L. lactis & 37 & 6 to 15 & $1 \cdot 97$ & trace & $I \cdot 97$ & $20 \cdot 0$ & $1 \cdot 97$ & $10 \cdot 2$ \\
\hline L. bulgaricus & 37 & 4 to 14 & $\mathrm{I} \cdot 95$ & 0.10 & 2.05 & $22 \cdot 0$ & $2 \cdot 15$ & $10 \cdot 2$ \\
\hline L. casei & 30 & 3 to 18 & $1 \cdot 85$ & $0 \cdot 18$ & 2.03 & $23 \cdot 4$ & $2 \cdot 21$ & $10 \cdot 6$ \\
\hline L. caseit & 30 & I to 5 & 0.80 & $I \cdot 23$ & $2 \cdot 03$ & $33 \cdot 3$ & $3 \cdot 26$ & $10 \cdot 2$ \\
\hline \multicolumn{9}{|c|}{ Galactose } \\
\hline L. plantarum & 30 & 6 to 16 & $1 \cdot 75$ & 0.38 & $2 \cdot 13$ & $25 \cdot 7$ & $2 \cdot 5 \mathrm{I}$ & $10 \cdot 2$ \\
\hline L. plantarum & 30 & I to 5 & $I \cdot 22$ & 0.88 & $2 \cdot 10$ & $30 \cdot 0$ & $2 \cdot 98$ & $10 \cdot 1$ \\
\hline L. plantarum $\ddagger \S$ & 30 & 1 to 5 & 0.97 & $1 \cdot 00$ & $1 \cdot 97$ & $32 \cdot 5$ & $2 \cdot 97$ & $10 \cdot 9$ \\
\hline \multicolumn{9}{|c|}{$\begin{array}{l}* \text { Not including } \mathrm{CO}_{2} \text {. } \\
\dagger \text { Mol lactate per mol substrate }+2 \text { (mol acetate per mol substrate). } \\
\ddagger \text { Complex medium. The defined basal medium was used for other tests. } \\
\S \text { Strictly anaerobic conditions. }\end{array}$} \\
\hline
\end{tabular}

deep-culture conditions, or galactose for glucose. Y(glucose) for Lactobacillus casei was appreciably greater if complex medium replaced the defined basal medium, but more acetate was produced in the complex medium, and the $Y(\mathrm{ATP})$ values corrected for energy produced during the production of acetate were essentially the same. Results for ethanol and formate are not included in Table $\mathrm{I}$, because each was rarely detected and, then, only in trace amounts.

\section{Incorporation of glucose into bacterial materials}

Results with Lactobacillus plantarum showed that glucose was used primarily as a source of energy and that the yields were not invalidated by the incorporation of glucose into bacterial components. The organism was grown in the basal medium containing 3 or $6 \mu \mathrm{mol}$ glucose $/ \mathrm{ml}$ plus $\left[\mathrm{U}-{ }^{14} \mathrm{C}\right]$ glucose $(0.0 \mathrm{I} 2$ or $0.024 \mu \mathrm{Ci} / \mathrm{ml})$. When growth ceased, the bacteria were washed and the lipids extracted (see Methods). Only $2.9 \%$ of the metabolized glucose was incorporated into the bacteria ( $\mathrm{I} \cdot \mathrm{I} \%$ in the lipids and $\mathrm{I} \cdot 8 \%$ otherwise assimilated). This is similar to findings for species of Streptococcus (Bauchop \& Elsden, I960; Harvey \& Collins, 1963).

\section{Influence of temperature on bacterial yields}

Before determining the molar growth yields for Lactobacillus lactis and L. bulgaricus, we determined $Y$ (glucose) values for these organisms at $40{ }^{\circ} \mathrm{C}$ at, or near, their optimum growth temperature (Bergey's Manual of Determinative Bacteriology, 1957), and found them to be 9.7 (L. lactis) and 9.4 (L. bulgaricus). Lactobacillus lactis at $40^{\circ} \mathrm{C}$ produced, per $\mu$ mol glucose, $\mathrm{I} .58 \mu \mathrm{mol}$ lactate and $0.47 \mu \mathrm{mol}$ acetate, and the $Y(\mathrm{ATP})$ value, calculated from these amounts, was $3 \cdot 9$. Lactobacillus bulgaricus produced, per $\mu \mathrm{mol}$ glucose, I.35 $\mu \mathrm{mol}$ lactate and $0.70 \mu \mathrm{mol}$ acetate, giving a $Y(\mathrm{ATP})$ value of 3.4 . As the species produced higher yields 
at $37^{\circ} \mathrm{C}, 40^{\circ} \mathrm{C}$ must have been outside the critical temperature range wherein the production of ATP is closely coupled to its utilization in the synthesis of bacterial mass (Senez, 1962; Forrest, 1967).

\section{DISCUSSION}

Each of the five species of Lactobacillus studied autolysed after attaining maximum growth on limiting amounts of glucose in the defined medium. Lactobacillum plantarum, however, did not lyse if galactose replaced glucose, suggesting that this species, similar to certain streptococci (Moustafa \& Collins, 1968 b), has difficulty synthesizing galactosamine from glucose. Autolysis was more severe if salts C (Henderson \& Snell, 1948) replaced salts B (MacLeod \& Snell, 1947). Thus, the low yield which Oxenburgh \& Snowswell (1965) obtained for this strain of $L$. plantarum on limiting glucose medium is explained: they used the same medium as we used but with salts $\mathrm{C}$ and, furthermore, determined bacterial yields after the cultures had been incubated for $48 \mathrm{~h}$ rather than at maximum extinction.

Our calculations of $Y(\mathrm{ATP})$ values assumed that lactate was produced by the EmbdenMeyerhof-Parnas (EMP) pathway with the simultaneous production of I net mol ATP/ mol lactate and that acetate was produced only with the simultaneous production of 2 net $\mathrm{mol}$ ATP/mol acetate, one during the formation of pyruvate by the EMP pathway and one during the conversion of pyruvate to acetate. Buyze, van den Hamer \& de Haan (1957) found enzymes of the pentose cycle absent from Lactobacillus lactis and L. delbrueckii, and likewise Machida, Mizushima \& Kilahara (1963) found the pentose cycle inoperative in $L$. plantarum during fermentation of hexose. Since only trace amounts of formate were produced by the lactobacilli, we conclude that acetate was produced from pyruvate either by the oxidation system reported for $L$. delbrueckii (Hager, Geller \& Lipmann, 1954) or the system that requires lipoic acid (O'Kane \& Gunsalus, 1948; O'Kane, I950), each of which yields I $\mathrm{mol} \mathrm{ATP} / \mathrm{mol}$ acetate.

The $Y$ (glucose) values for Lactobacillus lactis and L. bulgaricus determined at $40{ }^{\circ} \mathrm{C}$ were less than $50 \%$ of those determined at $37^{\circ} \mathrm{C}$, though, judging from the amounts of lactate and acetate produced, $L$. lactis produced as much ATP per mol of glucose at $40{ }^{\circ} \mathrm{C}$ as it did at $37^{\circ} \mathrm{C}$, and L. bulgaricus actually produced more ATP at $40^{\circ} \mathrm{C}$. This is another example of inefficient coupling of anabolic and catabolic processes (Gunsalus \& Shuster, I96r ; Forrest \& Walker, I965; Cole, Wimpenny \& Hughes, 1966). Senez (1962) suggested that maximum efficiency might occur only at temperatures within a restricted range, and Forrest (1967) found yields of Streptococcus faecalis and Zymomonas mobilis to drop at temperatures outside critical ranges. The ATP produced by L. lactis and L. bulgaricus at $40^{\circ} \mathrm{C}$ and not utilized in the synthesis of bacterial mass must have been hydrolysed by an adenosine triphosphatase system (Gunsalus \& Shuster, 196I), since the production of lactate and acetate accounted for all of the glucose utilized at both temperatures.

\section{REFERENCES}

BARker, S. B. \& Summerson, W. H. ( I 941 ). The colorimetric determination of lactic acid in biologic material. Journal of Biological Chemistry $\mathbf{1 3 8}, 535-554$.

Bauchop, T. \& Elsden, S. R. (1960). The growth of microorganisms in relation to their energy supply. Journal of General Microbiology 23, 457-469.

Bergey's Manual of Determinative Bacteriology (1957), 7th edn, p. 547. Edited by R. S. Breed, E. G. D. Murray and N. R. Smith. Baltimore: Williams \& Wilkins.

Brown, J. P. ( I968). Anomalous anaerobic growth yields of Lactobacillus casei strain 103 in complex medium. Applied Microbiology 16, 805-807. 
Brown, J. P. \& VANDEMARK, P. T. (1968). Respiration of Lactobacillus casei. Canadian Journal of Microbiology 14, 829-835.

Buyze, G., van den Hamer, C. J. A. \& De HaAn, P. G. (I957). Correlation between hexose monophosphate shunt, glycolytic system and fermentation type in lactobacilli. Antonie van Leeuwenhoek 23, 345-350.

Chayken, S. (1966). Biochemistry Laboratory Techniques, pp. 89-9I. New York: John Wiley.

Christensen, M. D., Albany, M. H. \& Pederson, C. S. (1958). Variation in the acetic acid-lactic acid ratio among the lactic acid bacteria. Applied Microbiology 6, 3 I6-3 I 8.

Cole, H., Wimpenny, J. W. T. \& Hughes, D. E. (1966). The adenosine triphosphate pool in Escherichia coli. Biochemical Journal roo, 81-82.

Elsden, S. R. \& Peel, J. L. (1958). Metabolism of carbohydrates and related compounds. Annual Reviews of Microbiology 12, 145-202.

Erkama, J., Kauppien, V. \& Heino, K. (i 968). Oxygen and microaerophilic bacteria. Growth and peroxidase activity of Lactobacillus casei. Acta chemica scandinavica 22, 2166-2 I 70.

FORREST, W. W. (1967). Energies of activation and uncoupled growth in Streptococcus faecalis and Zymomonas mobilis. Journal of Bacteriology 94, I459-I463.

Forrest, W. W. \& WALKer, D. J. (I965). Control of glycolysis in washed suspensions of Streptococcus faecalis. Nature, London 207, 46-48.

Gunsalus, I. C. \& Shuster, C. W. (196I). Energy yielding metabolism in bacteria. In The Bacteria, vol. 2, pp. I-58. Edited by I. C. Gunsalus and R. Y. Stanier. New York: Academic Press.

Hager, L. P., Geller, D. M. \& LipmanN, F. (I954). Flavoprotein catalysed pyruvate oxidation in Lactobacillus delbrueckii. Federation Proceedings $\mathbf{1 3}, 734-738$.

Harvey, R. J. \& Collins, E. B. (1963). Roles of citrate and acetoin in the metabolism of Streptococcus diacetilactis. Journal of Bacteriology 86, I30I-I 307.

Henderson, L. M. \& Snell, E. E. (1948). A uniform medium for determination of amino acids with various microorganisms. Journal of Biological Chemistry 172, 1 5-29.

MacLeod, R. A. \& SNell, E. E. (1947). Some mineral requirements of the lactic acid bacteria. Journal of Biological Chemistry I70, 35I-365.

Machida, Y., Mizushima, S. \& Kilahara, K. (1963). Quantitative studies on glycolytic enzymes in Lactobacillus plantarum. 4. Intracellular activity of glucose-6-phosphate dehydrogenase during lactic acid fermentation. Journal of General and Applied Microbiology 9, 433-442.

Moustafa, H. H. \& Collins, E. B. (I968a). Molar growth yields of certain lactic acid bacteria as influenced by autolysis. Journal of Bacteriology 96, I $17-125$.

Moustafa, H. H. \& Collins, E. B. ( $1968 b$ ). Role of galactose or glucose-I-phosphate in preventing the lysis of Streptococcus diacetilactis. Journal of Bacteriology 95, 592-602.

Neish, A. C. (1950). Analytical Methods for Bacterial Fermentations, pp. 16-17. Report no. 46-8-3. Saskatoon: National Research Council of Canada.

O'KANE, D. J. (1950). Influence of the pyruvate oxidation factor on the oxidative metabolism of glucose by Streptococcus faecalis. Journal of Bacteriology 6o, 449-458.

O'Kane, D. J. \& Gunsalus, I. C. (1948). Pyruvic acid metabolism. A factor required for oxidation by Streptococcus faecalis. Journal of Bacteriology 56, 499-506.

OXenburgh, M. S. \& SNowswell, A. M. (1965). Use of molar growth yields for the evaluation of energyproducing pathways in Lactobacillus plantarum. Journal of Bacteriology 89, 9I3-9I4.

SENEZ, J. C. (1962). Some considerations on the energetics of bacterial growth. Bacteriological Reviews 26, 95-107.

Stouthamer, A. H. (1969). Determination and significance of molar growth yields. In Methods in Microbiology, vol. I, pp. 629-663. Edited by J. R. Norris and D. W. Ribbons. New York: Academic Press.

de Vries, W., Kapteijn, W. M. C., van der Beek, E. G. \& Stouthamer, A. H. (1970). Molar growth yields and fermentation balances of Lactobacillus casei $\mathrm{L}_{3}$ in batch cultures and in continuous cultures. Journal of General Microbiology 63, 333-345.

Weinfurtner, F., Uhl, A. \& OTt, H. (1960). Die Bedeuntung des gelösten Sauerstoffs für die Vermehrung der Mikroorganismen. Archiv für Mikrobiologie 36, I-22.

Wood, H. G. \& GeST, H. (I957). Determination of formate. In Methods in Enzymology, vol. 3, p. 385. Edited by S. P. Colwick and N. O. Kaplan. New York: Academic Press. 